\title{
A Brief Review on Bitter Apple - Pharmacological Activities
}

\author{
Rashmi Sagar* and V.K. Dumka \\ Department of Veterinary Pharmacology and Toxicology, Guru Angad Dev Veterinary and \\ Animal Sciences University, Ludhiana-141001, Punjab, India \\ *Corresponding author
}

\section{A B S T R A C T}

\section{Keywords}

Bitter apple, Citrullus colocynthis (L.) Schrad.

(Cucurbitaceae)

Article Info

Accepted:

04 November 2018

Available Online:

10 December 2018
Present review article reveals the importance of Bitter Apple belonging to the species Citrullus colocynthis, distributed in India and other parts of the world; this extensive research information on this species is highly significant for future researchers worldwide. As per Ayurveda and Siddha system of medicine it is Tikta-rasam, ushna-veeryam and katuvipakam and used as purgative, diuretic, lagu, kapharam and abortifacient. Fruit is bitter, pungent and used as purgative, anthelmintic, antipyretic, carminative, cures tumors, leucoderma, ulcers, asthma, etc. Root is useful in jaundice, ascites, urinary disease, rheumatism. In this article pharmacological and biological activity, inputs have been extensively recorded and discussed.

\section{Introduction}

Bitter Apple also known as Citrullus colocynthis (L.) Schrad. (Cucurbitaceae) has medicinal and ornamental purposes, the former derived primarily from the fruit pulp (de Smet, 1997).

Common names for this plant include colocynth, bitter gourd, bitter apple, and bitter cucumber in English while it is known as Koloquinthe in German and coloquintein French (de Smet, 1997). C. colocynthis has only one accepted name but six synonyms (The Plant List, 2017).

In India and Pakistan, it is known as tumba (Mahajan and Kumawat, 2013; Hussain et al., 2014).

\section{Importance and Uses}

According to Hussain et al., (2014), C. colocynthis has the following traditional medicinal uses: "diabetes, leprosy, common cold, cough, asthma, bronchitis, jaundice, joint pain, cancer, toothache, wound, mastitis, and in gastrointestinal disorders such as indigestion, constipation, dysentery, gastroenteritis, colic pain and different microbial infections." Also, according to the same authors, who wrote a comprehensive review on several properties of $C$. colocynthis, indicated that there are multiple medicinal and biological activities, including antidiabetic, anticancer, cytotoxic, antioxidant, antilipidemic, insecticidal, antimicrobial and anti-inflammatory. De Smet (1997) also reviewed earlier literature on the 
medicinal properties of C. colocynthis. Several accessions have shown resistance to several viruses and diseases (Dabauza et al., 1997). Dabauza et al., (1997) developed an Agrobacterium tumefaciens-mediated genetic transformation protocol in which 7-day-old seedling cotyledons were infected with strain LBA4404 carrying the binary vector pBI121, harboring the $\beta$-glucuronidase (gus; reporter) and the neomycin phosphotransferase (nptII; marker) genes. Based on GUS expression, $14 \%$ of explants were shown to be transformed. PCR confirmed the integration of the gusand nptIIgenes while Southern blot analysis conferred transmission of the gusgene to several transgenic plants obtained by selfing. C. colocynthis is able to withstand extreme desert temperatures through a high rate of transpiration to lower leaf temperatures below lethal temperatures (Althawadi and Grace, 1986)

\section{Anti-inflammatory and analgesic activity}

Marzouk et al., 2011 studied aqueous extracts of C. colocynthis fruit and seed at an immature stage for anti-inflammatory activity using the carrageenan-induced paw edema assay in rats.

The best anti-inflammatory activities were obtained with immature fruits from south Tunisia. Therefore, C. colocynthis could be a useful product suitable for further evaluation for inflammatory diseases.

Methanol extract of Citrullus colocynthis significantly inhibited carrageenan, serotonin and prostaglandin E1-induced paw edema. Maximum inhibition was observed in prostaglandin E1-induced paw edema. In carrageenan air-pouch model, methanol extract of Citrullus colocynthis significantly reduced the volume of exudate and migration of neutrophils and monocytes. The extract significantly decreased formation of granuloma tissue in chronic inflammation model. Hence, this investigation established some pharmacological evidences to support the use of Citrullus colocynthis as antiinflammatory agent (Rajamanickam et al., 2010).

\section{Anticandidal and antibacterial activity}

Bactericidal activities of crude extracts, fractions and compounds of Citrullus colocynthis plant aerial parts and ripe deseeded fruits were performed against the drug sensitive standard strain of Mycobacterium tuberculosis H37Rv (ATCC 27294), 16 drug resistant strains of Mycobacterium tuberculosis and two Mycobacterium other than tuberculosis (MOTT) strains, using radiometric BACTEC system. Methanolic extract of ripe deseeded fruit of Citrullus colocynthis showed good activity (MIC $\leq 62.5 \mu \mathrm{g} / \mathrm{ml})$ and one of the bioactive fractions demonstrated the best activity (MIC $31.2 \mu \mathrm{g} / \mathrm{ml}$ ) against Mycobacterium tuberculosis H37Rv (Mehta et al., 2013).

The maximum antimicrobial activity was exhibited by acetone, ethanol, methanol and distilled water extract of the fruits of Citrullus colocynthis against Escherichia coli, Staphylococcus aureus, Salmonella typhi, Shigella shigellae and Candida albicans. Whereas petroleum ether extract was found to be less effective against test strains (Rodge and Biradar 2013).

In the study conducted by Sagar et al., 2018 various extractsviz alcoholic, acetone, chloroform of the leaves of Citrullus colocynthis were evaluated for antibacterial activity against Staphylococcus aureus and E.coli and it was observed that none of the extracts showed antibacterial activity against both the bacteria when compared to standard antibiotic. 


\section{Antioxidant potential}

The antioxidant effects of Citrullus colocynthis seeds extracts [a crude aqueous extract (E1), a defatted aqueous extract (E2), a hydromethanolic extract (HM), an ethyl acetate extract (EA) and a $n$-butanol extract $(n-\mathrm{B})]$ were studied at a concentration of 2 $000 \mu \mathrm{g} / \mathrm{ml}$ in a 1,1-diphenyl-2-picrylhydrazyl assay, reducing percentage of $88.8 \%$ with EA, $74.5 \%$ with $\mathrm{HM}$ and $66.2 \%$ with E1 was recorded with a corresponding IC50 of 350, 580 and $500 \mu \mathrm{g} / \mathrm{ml}$ respectively as compared to $1.1 \mu \mathrm{g} / \mathrm{ml}$ for ascorbic acid (Benariba et al., 2013).

Antioxidant activity of Citrullus colocynthis seed methanolic extract was studied spectrophotometrically by 1, 1-diphenyl-2picryl hydrazyl and hydrogen peroxide free radical scavenging method. The methanolic seed extract of Citrullus colocynthis showed maximum percentage inhibition of 79.4 and $72.4 \%$ by 1, 1-diphenyl-2-picryl hydrazyl and hydrogen peroxide method respectively at 300 $\mu \mathrm{g} / \mathrm{ml}$ (Gill et al., 2011).

In vitro antioxidant studies revealed that, maximum percentage inhibition of DPPH radicals by methanolic extract of Citrullus colocynthis fruits (MECC) was $62 \%$ at 800 $\mu \mathrm{g} / \mathrm{ml}$. In the nitric oxide radical scavenging model, the maximum percentage inhibition by MECC was about $56 \%$ at $800 \mu \mathrm{g} / \mathrm{ml}$. From the study, it was concluded that MECC demonstrated dose dependent antioxidant activity comparable with ascorbic acid (Jayaraman and Christina 2013).

\section{Hypoglycemic activity}

Agarwal et al., 2012 examined the effect of root of $C$. colocynthis on the biochemical parameters of normal and alloxan-induced diabetic rats. Diabetes mellitus was induced by intraperitoneal $(120 \mathrm{mg} / \mathrm{kg}$ b.wt.) injection of alloxan monohydrate for three days and the animals showing blood glucose level in the range of $175-300 \mathrm{mg} / \mathrm{dL}$ were selected for study. The blood glucose concentrations of the animals were measured at the beginning of the study and the measurements were repeated on 3 rd, $5^{\text {th }}$ and $7^{\text {th }}$ day after the start of the experiment. Aqueous extract of roots of Citrullus colocynthis showed significant reduction in blood sugar level $(58.70 \%)$ when compared with chloroform (34.72\%) and ethanol extracts (36.60\%). The aqueous extracts showed improvement in parameters like body weight, serum creatinine, serum urea and serum protein as well as lipid profile and also restored the serum level of bilirubin total, conjugated bilirubin, serum glutamate oxaloacetate transaminase (SGOT), serum glutamate pyruvate transminase (SGPT) and alkaline phosphatase (ALP).

The direct in vitro effects of Citrullus colocynthis seed extracts were evaluated in glucose-stimulated insulin release from pancreatic islets isolated from rats. Six extracts were tested, a crude aqueous, defatted aqueous, ethyl acetate, $\mathrm{H}_{2} \mathrm{O}$-methanol, nbutanol extract and an extract containing a mixture of the major component (fraction A) (identified by gel chromatography in the ethyl acetate), n-butanol and $\mathrm{H}_{2} \mathrm{O}$-methanol extracts. The majority of extracts exhibited a positive insulinotropic action when tested in the presence of $8.3 \mathrm{mM} \mathrm{D}$-glucose (Benariba et al., 2013).

The effect of Citrullus colocynthis pulp extract on the structure of the liver was tested in diabetic rats at both light and scanning electron microscopic levels. Diabetes caused degenerative alterations in the form of disorganization of the hepatic cords, cytoplasmic vacuolization and pyknosis of the nuclei of hepatocytes and inflammatory cell infiltration. Scanning electron microscope examination of these livers revealed 
numerous lipid droplets within hepatocytes, damaged blood sinusoids and hemorrhage of erythrocytes between hepatocytes and inside Disse's spaces. The liver of Citrullus colocynthis -treated rats revealed minor histological changes versus the control animals (Khalil et al., 2010).

\section{Anti - alopecia activity}

Dhanotia et al., 2011 evaluated C. colocynthis for hair growth activity in androgen-induced alopecia. Petroleum ether extract of $C$. colocynthis was applied topically for its hair growth-promoting activity. Alopecia was induced in albino mice by testosterone administration intramuscularly for 21 days. Its inhibition by simultaneous administration of extract was evaluated using follicular density, anagen/telogen $(\mathrm{A} / \mathrm{T})$ ratio and microscopic observation of skin sections. Finasteride $(5 \alpha-$ reductase inhibitor) solution was applied topically and served as positive control. Petroleum ether extract of $C$. colocynthis exhibited promising hair growth promoting activity, as reflected from follicular density, $\mathrm{A} / \mathrm{T}$ ratio and skin sections. The treatment was also successful in bringing a greater number of hair follicles in anagenic phase than the standard finasteride. The result of treatment with 2 and $5 \%$ petroleum ether extracts were comparable to the positive control finasteride. The petroleum ether extract of $C$. colocynthis and its isolate was found useful in the treatment of androgeninduced alopecia.

Petroleum ether and ethanol extracts of Citrullus colocynthis were tested for their effect on hair growth in albino rats. The extracts incorporated into oleaginous ointment base were applied topically on shaved denuded skin of albino rats. The time required for initiation of hair growth as well as completion of hair growth cycle was recorded. Minoxidil 2\% solution was applied topically and served as the standard. Hair growth initiation time was significantly reduced to half on treatment with the petroleum ether extracts compared with untreated control animals. The time required for complete hair growth was also considerably reduced. The treatment was successful in bringing a greater number of hair follicles $(>70 \%)$ to anagenic phase than standard minoxidil (67\%). The result of treatment with 2 and $5 \%$ petroleum ether extracts were comparable with the standard minoxidil (Roy et al., 2007).

\section{Antiparasitic insecticidal and antiscorpion effects}

Albino mice were intraperitionally infected with promastigotes of Leishmania donovani (MHOM/ IQ/ 982/BRCI) strain. The inoculation of albino mice caused elevation of liver and spleen weight after 7-15 days. The mice treated with $20-100 \mathrm{mg} / \mathrm{kg}$ from Citrullus colocynthis showed decreased average liver and spleen weight in comparison to the positive control. The most important histopathologcal results in the positive control including scattered necrosis, lymphatic infiltration, proliferation of macrophages and a variable number of leishman bodies were observed and it was noted that $80-100 \mathrm{mg} / \mathrm{kg}$ of Citrullus colocynthis returned liver section to normal histology (Al-Harmni et al., 2012).

Methylene chloride, n-hexane, chloroform and ethanol extracts of Citrullus colocynthis fruits were tested against Aphis craccivora. The highest insecticidal effect (LC50: 11003 ppm) was obtained from the ethanol extract. The residue remaining after evaporation of ethanol extract was re-extracted by different solvents with increasing polarity. Each fraction was tested against Aphis craccivora. The butanol extract showed the maximum insecticidal effect. The effective compound 
was identified as 2-O- $\beta$-Dglucopyranosylcucurbitac in E (Torkey et al., 2009).

Citrullus colocynthis was evaluated as new therapeutic approach for scorpion envenomation mainly Androctonus australis hector venom (Aah). Local action (paw edema) and systemic effects (inflammatory, metabolic parameters, oxidative stress and hyperglycemia) were studied in pretreated mice with Citrullus colocynthis $(50 \mathrm{mg} / \mathrm{kg})$; $30 \mathrm{~min}$ before injection of sublethal dose of Androctonus australis hector venom (10 $\mu \mathrm{g} / 20 \mathrm{~g})$. Results showed that injected Citrullus colocynthis extract before envenomation was able to protect animals against the toxicity of the venom. It significantly reduced paw edema, cell migration, exudation and hyperglycemia. Citrullus colocynthis decreased also some inflammatory markers (MPO and EPO activities, CRP and C3) and maintain the level of CPK, ASAT and ALAT. So, it was concluded that Citrullus colocynthis appeared to be a potential tool that can reduce pathophysiological effects induced after envenomation (inflammation and oxidative stress) (Fatima and Mohamed 2014).

\section{Growth inhibitory activity on breast cancer cells}

Grossman et al., 2007 studied the effects of cucurbitacin glycosides extracted from Citrullus colocynthis leaves on human breast cancer cell growth. Leaves were extracted, resulting in the identification of cucurbitacin $\mathrm{B} / \mathrm{E}$ glycosides. The cucurbitacin glycoside combination (1:1) inhibited growth of ER (+) MCF-7 and ER (-) MDA-MB-231 human breast cancer cell lines. Cell-cycle analysis showed that treatment with isolated cucurbitacin glycoside combination resulted in accumulation of cells at the $\mathrm{G}(2) / \mathrm{M}$ phase of the cell cycle. Treated cells showed rapid reduction in the level of the key protein complex necessary to the regulation of $\mathrm{G}$ (2) exit and initiation of mitosis, namely the p34 (CDC2)/cyclin B1complex. Cucurbitacin glycoside treatment also caused changes in the overall cell morphology from an elongated form to a round-shaped cell, which indicates that cucurbitacin-treatment caused impairment of actin filament organization. This profound morphological change was thought to influence intracellular signaling by molecules such as $\mathrm{PKB}$, resulting in inhibition in the transmission of survival signals. Reduction in PKB phosphorylation and inhibition of survivin, an anti-apoptosis family member, was observed. The treatment caused elevation in p-STAT3 and in p21 (WAF), proven to be a STAT3 positive target in absence of survival signals. Cucurbitacin glycoside treatment also induced apoptosis, as measured by Annexin V/propidium iodide staining and by changes in mitochondrial membrane potential (DeltaPsi) using a fluorescent dye, JC-1. It was suggested that cucurbitacin glycosides exhibit pleiotropic effects on cells causing both cell cycle arrest and apoptosis. These results indicated that cucurbitacin glycosides might have therapeutic value against breast cancer cells.

The paper reviewed Citrullus colocynthis as promising medicinal plant with wide range of pharmacological activities which could be utilized in several medical applications because of its effectiveness and safety.

\section{References}

Agarwal, V.I.P.I.N., Sharma, A.K., Upadhyay, A.N.S.H.U., Singh, G.O.P.E.N.D.R.A. and Gupta, R.A.J.I.V., 2012. Hypoglycemic effects of Citrullus colocynthis roots. Acta Pol Pharm, 69(1), pp.75

Al-Harmni, K.I., Rahemo, Z.I. and Al-Khan, H.I., 2012. The effect of two fruit 
extracts and drugs on the liver of albino mice with induced leishmaniasis. Trends in Parasitology Research, 1(3), pp.16-26

Althawadi, A.M. and Grace, J., 1986. Water use by the desert cucurbit Citrullus colocynthis (L.) Schrad. Oecologia, 70(3), pp.475-480.

Benariba, N., Djaziri, R., Bellakhdar, W., Belkacem, N., Kadiata, M., Malaisse, W.J. and Sener, A., 2013. Phytochemical screening and free radical scavenging activity of Citrullus colocynthis seeds extracts. Asian Pacific journal of tropical biomedicine, 3(1), p.35.

Dabauza, M., Bordas, M., Salvador, A., Roig, L.A. and Moreno, V., 1997. Plant regeneration and Agrobacteriummediated transformation of cotyledon explants of Citrullus colocynthis (L.) Schrad. Plant Cell Reports, 16(12), pp.888-892.

Dane, F. and Liu, J., 2007. Diversity and origin of cultivated and citron type watermelon (Citrullus lanatus).Genetic Resources and Crop Evolution, 54(6), pp.1255-1265.

De Smet, P.A.G.M., 1997. Citrullus colocynthis. In Adverse effects of herbal drugs (pp. 29-36). Springer, Berlin, Heidelberg

Dhanotia, R., Chauhan, N.S., Saraf, D.K. and Dixit, V.K., 2011. Effect of Citrullus colocynthis Schrad fruits on testosterone-induced alopecia. Natural product research, 25(15), pp. 14321443

Fatima, L.D., Mohamed, K. and Ezzouar, B., 2014. Phytotherapy as new approach to treat scorpion envenomation: experimental study. IJPSR, 5(5), pp. 1682-1692.

Gill, N.S., Bajwa, J., Dhiman, K., Sharma, P., Sood, S., Sharma, P.D., Singh, B. and Bali, M., 2011. Evaluation of therapeutic potential of traditionally consumed Cucumismelo seeds. Asian Journal of Plant Sciences, 10(1), p.86.

Grossman S, Dovrat S, Gottlieb H E and Bergman. 2007. M Growth inhibitory activity of cucurbitacin glucosides isolated from Citrullus colocynthis on human breast cancer cells. Biochem Pharmacol. 73(1): 56-67

Hussain, A.I., Rathore, H.A., Sattar, M.Z., Chatha, S.A., Sarker, S.D. and Gilani, A.H., 2014. Citrullus colocynthis (L.) Schrad (bitter apple fruit): A review of its phytochemistry, pharmacology, traditional uses and nutritional potential. Journal of ethnopharmacology, 155(1), pp.54-66.

Jayaraman, R. and Christina, A.J.M., 2013. Evaluation of Citrullus colocynthis fruits on in vitro antioxidant activity and in vivo DEN/PB induced hepatotoxicity. International Journal of Applied Research in Natural Products, 6(1), pp.1-9.

Mahajan, S.S. and Kumawat, R.N., 2013. Study of seed dormancy in colocynth (Citrullus colocynthis L.) with afterripening of fruits, seed extraction procedures and period of seed storage.National Academy Science Letters, 36(4), pp.373-378.

Marzouk, B., Marzouk, Z., Fenina, N., Bouraoui, A. and Aouni, M., 2011. Anti-inflammatory and analgesic activities of Tunisian Citrullus colocynthis Schrad. Immature fruit and seed organic extracts. Eur Rev Med PharmacolSci, 15(6), pp.665-72.

Mehta, A., Srivastva, G., Kachhwaha, S., Sharma, M. and Kothari, S.L., 2013. Antimycobacterial activity of Citrullus colocynthis (L.) Schrad. against drug sensitive and drug resistant Mycobacterium tuberculosis and MOTT clinical isolates. Journal of 
ethnopharmacology, 149(1), pp.195200.

Rajamanickam, E., Gurudeeban, S., Ramanathan, T. and Satyavani, K., 2010. Evaluation of anti-inflammatory activity of Citrullus colocynthis. International Journal of Current Research, 2, pp.67-69.

Rodge, S.V. and Biradar, S.D., 2012. Preliminary Phytochemical screening and antimicrobial activity of Citrullus colocynthis (Linn.) Shared. Indian J. Plant Sci, 2(1), pp.19-23.

Roy, R.K., Thakur, M. and Dixit, V.K., 2007. Effect of Citrullus colocynthis. On hair growth in albino rats. Pharmaceutical biology, 45(10), pp.739-744.

Sagar, R., Dumka, V.K., Kaur, R. and Singla, S. 2018. Evaluation of antiinflammatory, antibacterial and acaricidal activities of various leaf extracts of Pongamia pinnata. Journal of Phytochemistry and Pharmacognosy 7(1): 2464-2467.

Torkey, HM, A.Y., AZ, A.A. and Farid, H., 2009. Insecticidal effect of cucurbitacin E glycoside isolated from Citrullus colocynthis against Aphis craccivora.

\section{How to cite this article:}

Rashmi Sagar and Dumka, V.K. 2018. A Brief Review on Bitter Apple - Pharmacological Activities. Int.J.Curr.Microbiol.App.Sci. 7(12): 281-287.

doi: https://doi.org/10.20546/ijcmas.2018.712.034 